\title{
Mental Health Services in Primary Care
}

- Nita Pokharel*

\begin{abstract}
Absiraot:-
"Health for All" can not be achieved unless the mental health services is integrated in primary health care. Psychiatric services available in Kathmandu Valley is inadequate and inacceble to most of the people in Nepal. Time has come to decentralize the psychiatric services to different workers of health profession other than the psychiatrists. Courses on psychiatry should be included in the curriculum of medicine and nursing in the certificate and auxilliary programmes. Experimental studies including mental health services should be started in some heaith posts.
\end{abstract}

W. H. O. defines health as a "state of complete physical, mental and social well being, not merely the absence of disease". Howover in reality there is very little recognition of the mental health aspects in the general health programmes. Mental health problem is a world wide problem. It is increasing day by day in both the developed and developing countries. Studies conducted by W. H. O. in 1975 state that there are $1 \%$ of the population suffering from a major mental illness at any time excluding the alcoholics and $10 \%$ are suffering at some time during their life. Another report of W. H. O. expert committee states that there are about $\mathbf{4 0}$ million currently suffering from mental illness in the devcioping countries, and most of them are not receiving adequate treatment. Mental illness causes problems to the individual, family, community, health planner, educationists, and health care providers. Alma Ata declaration of "Health for All" would not be possible unless the mental bealth component is integrated in the primary health care. One should not forget that "Promotion of Mental Health and Provision of Essential Drugs" form one of the eight components of P.H.C. It is quite possible that the patient receiving different health care facilities are prinarily suffering

\footnotetext{
* Lecturer, Mahaboudha Nursiog Campus I.O.M.
} 
from psychosocial problem and that remain unnoticed in rest cates. If such problems are recogaized in the initial stage, lots of money and time of the patient can be saved. At the same time doctors can have time to tackle patient with serious problems more efficiently.

Nepal has very little epidemiological data relating to the distribution and prevalence of mental disorder. According to Peterstone 1977, I- $2 \%$ of Nepal's population is sulfering from serious mental ithness. According to Kapur $1979,25 \%$ are suffering from personality and reactive disorders. Shrestha D. M. estimates that there are about 280,000 population suffering from mental jllness in Nepai. But the facilities for mental health care is very much scarce and whatever facility is provided is in the capital. There is one 50 bedded mental hospital in Lalitpur district; and 16 psychiatric beds in Military Hospical in Kathmandu district and few private nursing homes run by the psychiatrists.

There is a severe shortage of phychiatrist and psychiatric nurse in our country. There are only 8-10 psychiatrists and 2 psychiatric nurses is our country, they are also working in the capital. According to 198 i census Nepal has a population of $15,020,451$ and $96 \%$ of people live in rutal areas. Therefore the centraliy located psychiatric serviees are not accessible to the rura! population. As Nepal is a landlocked country, lack of transport and communication is a major problem. The rural peopie find difficulty to bring the patient to the capital in the early state of mental illness. The obstacle is more strengthened up by the people's artitude of viewing mental disorders from religious, superstitious and magical stand point and thus walk for medical help only as the last resort. On the other side lack of avaitable services at their access means that the traditional healers are seen as the only source of belp. Therefore they wander from village to village seeking help from traditional healers and religious heads. When the case seems to be unmanagable the patient is either locked or handed over to the police very few patients arrive at Kathmandu and fow go to India for psychiatric treatment.

According to the 6th 5 year plan targets, basic health services will be provised to the people throughout the country through the health posts in an integrated manner. But these is no facitities for the treatment of mentally ill in this setting. There is no provision of psyctiatric coutse in the curriculum up to the certificate level of mediciae and oursing in the country. Therefore the majority of the people on the health profession working in the village level have very litite knowledge of psychiatry.

Since the psychiatric service in our country is vercy inadequate and inâcéssible to the 
majorty of the poputation, the community based psychatric service integrated with primary health care system may prove most appropriate: Thercfore it seems-quite natural to think different allernatives to include mental health care in primary health care: ${ }^{2}$

1. Decentralization of psychiatric services. There are very encouraging example of different approaches to mental health care in developing countries utilizing different category of personnel. For example rural doctors in Alexandroupolis (Grecce, 1981) family health educators and psychiatric nurses in Botswana (Africa 1980), community in general in Nigeria (Lambo 1966), hospital assistants in Sarawak (Schmidt 1567), public health nurses in Colombia (Argandona and Kiev, 1972), medical assistants in Zambia and Uganda (Egdell, 1970). Psychiatrists as Baan (1968), Baasher (1972), Carstairs (1973), Collomb (1973) have stresjed the need for training mental health workers and planning services in the developing countries. Kenya, Rwanda and Zambia are also currently making efforts to decentralize mental health services and integrate them into the general health services:

Different categories of workers providing ptimary health care must be guided; supported and supervised about essential aspects of mental health so that they could identify the mental illness in the earlier stage. give necessary support, provide emergency piychiatric care and refer the case to the appropriate place. Periodical in-service education should be arranged for this.

a. A task oriented approach may be most suitable. The priority condition should be laid down. Sinple task should be delegated to the less trained workers and complex task to the more qualificd ones. In the case of integrated health post village health workers could be encouraged to identify the case, give information to the family about emotional ard social behaviour of the patient, knowing family background and he the connecting link betwcen health post, mental health worker and the patients. In case of unintegrated :health post some volunteers from the panchayat, teacher group or elderly pcople could be trained for the same purpose. Eyen the traditional healers could be. included $\therefore-\therefore$ in an experimental basis as they are already involved in treating psychological iliness; in, different developing countriesas a botanist, pharmacist, doctors, psychiatrist, and social workers. Auxilliary N̦urse Midwife, Auxillary. Health Worker; Health Assistants could be trained in providing emergency psychiatric care, group discussion, examining psychiatric pattient and prescribing the essential drugs. 
b. Thete should be periodical supervision and surveillance by the trained personnel of the care provided by the newly trained personnel.

c. A training manual should be developed depending upon the epidemiological survey and priority need. The manual should include examples of the patient, symptoms, diagnostic methods and helping approaches.

d. In the initial stage the health workers may need some emotional support to deal with people suffering from mental iliness.

2. Curriculum revision and development.

In order to include mental health care in primary health care system, a curriculum on psychiatry shou!d be developed and implemented in bealth workers' training programme e.g. in the health assistant course, certificate in general medicine, nursing, auxillary nurse midwife programme and so on. This will be of great importance for the future development of mental health programme in the country. Recently psychiatric curriculum is being included in different developing countries. China is an example of the country where psychiatric curriculum is included in the medicine $(1978,1979)$. Many seminars were conducted in China along with the help of W.H.O. regarding psychiatry and mental health.

\section{Research Studies.}

Some experimental rescarch study of mental health care including mental health in primary bealth care should be started at one or more district in the country. Depending upon the evaluation of the experimental study a detailed plan to provide mental health services all over the country can be developed. Let us review the recent development of the mental bealth care in some of the countries.

a. In Tanzunia, mental health programme committee coordinate, mental bealth education to develop strategies and programmes for the management and rehabilitation of mentally ill patient in the community, involving local community leaders and religious heads.

b. During 1975 W.H.O. started conducting research with an aim to discover priority of need and relevant provisions of psycbiatric services at P.H.C. in different developing countries. The countries under study were India (Chandighar), Philippines (Mapila). Sudan (Khartoum Province), Columbia (Cali), Senegal, Brazil and Egypt. The study used a self reporting questionnaire and present state examination questionaire to the 
patients attending health centre. India, Sudan and Philippines used community leaders to spell the name of patient and traditional healers in their area. They found the mental disorders $10.8 \%$ in Columbia, $17.7 \%$ in India, $10.6 \%$ in Sudan and $16.3 \%$ in Philippines. The psy chiatric priorities wcre psychiatric emergencies, acute and chronic psychosis, attert ped suicide, effects of drugs and alcohol, grandmal epilepsy, neuroses and mental retardation. More thian $50 \%$ patient in Philippines, $50 \%$ in Sudan $25 \%$ in India go to traditional healers for help.

c. In Botswana, the traditional role of the hospital based psychiatric care is being expanded to commuvity, integrated with a primary care system: a country-wide service in 1980. The family welfare educationers (village health workers) were given 11 weeks traiting on motivation, prevention, management of psychiatric emergencies and referral system. The psychiatric nurses were retrained and posted to the community to promotemental health. to prevent specific mental health problem, to identify, manage and follow up psychiatric patients within the context of the family and community. Supervision of the nurses were done by psychiatrists. The impact of the programme was that admissions to the mental hospital were reduced to half and net saving of one tenth of the drug expenditure for the country and no additional cost in the programme.

d. In 1981, one research progranune of an experimental community mental health care was conducted in the remote district of Alexandroupolis in Greece with the objective of accrssibility of service and continuity of care in the villages and small towns. Educa. tion and reorientation was given to the rural doctors to perform psychiatric diagnosis. drug prescription, consaltation, supportive psychotherapy and refertal services.

c. In Lesotho, multipurpose health workers in 120 rutal clinics are trained to identify, manage and follow-1.p patient withio P.H.C. The multipurpose health workers were qualified nurse midwifes with furthes one year task oriented course. The course cnable them to ilentify, maiage, refer $90 \%$ of patients with all bealth problems including mental health problems; nurse clinicians also cocrdinate the training of V.H.W. in their arcas.

\section{Referencas}

1. H.G. Egdell (1983), Mental Health care in the developing wurld. Tropical Doctor Oet. $149-152$

2. World Health Organization (1975) Organization of Mental Health Services in Develop- 
ing Countries. Technical. Report Servies No 564.

3. R. Giel and T.W. Harding (1976) Psychiatric Priorities in Developing Countries Britssh Journal of Psychiatry, 128, 513.22.

4. John E. Cuoper (1982) Seminars in Cbina World Health October 23-25

3. D.I.B. Tovin (1982) Community Based Care World Health Oct. 1982 12-15

. 6. C.S. Lerodiakonou (1984) Mental Health and Primary Care in Greece, World Health Forum, Vol 5 No, 2120-122

7. D.M. Shrestha and others (1983) A Social and Psyehriatic study of Mental Illness in Nepal. International Year of disabled person committee Nepal Handicapped Sэrvices. Coordination Committee, United Nations Children Fund.

8. Carola Eisenberg. (1980), Honduras Mental Health awareness Changes a Community World Health Form $1(1,2) 72-77$.

LIVOMYN

LIVOMYN

LIVOMYN

TABLETS DROPS

SYRUP

\section{As You Like It!}

Regulates liver functions; promotes bile secretion

Protects liver from damage likely to be induced by drugs, toxins or alcohol

8 Accelerates liver repair following acute or chronic liver diseases

12 Tones up the entire digestive system: relieving indigestion, correcting constipation, stimulating appetite and weight gain

Cuts short convalescence period.

\section{Charak Pharmaceuticals (India) Pvt. Ltd. Bombay 40001 ?}

